\title{
How Does Faith Feel?
}

The Language and Affect of Belief

\author{
Callan Schultz \\ Freie Universität Berlin \\ callan.schultz@anu.edu.au
}

\begin{abstract}
Research on emotion in anthropology has been supplanted by an ethnographic turn toward 'subjectivity', 'embodiment', 'personhood', and 'experience'. In this article, I explore how these interrelated modes of analysis can help ethnographers to better understand the cultural processes that constitute how people feel. I show that among my Christian Dusun interlocutors in Ranau, Malaysian Borneo, the interactive engagement between subjects and their environment determined the vectors of emotional possibility in terms of belief. The intersection of religious objects (God, the Holy Spirit, Satan) and mutual obligations in the community produce what I refer to as the 'faith network'. I trace these collective attachments to consider how 'believing in' regulates feeling in relation to situations of crisis, impasse, and tragedy. The combined efforts of my interlocutors, I suggest, created an active commitment that pulsated through the faith network, which sustained an intensive and defining mode of their relational experience.
\end{abstract}

\section{Keywords}

Borneo - Malaysia - Dusun - Christianity - religion - affect - language - belief

\section{Introduction}

One Sunday morning, midway through my fieldwork, I waited in my adopted household for my friend, whom I will call 'Alexander', to pick me up to attend a cell group in a nearby kampung (village). When he arrived, I was surprised to see that our other friend, 'Jaki', was sitting in the backseat. Although Jakia church leader, husband, and father to a young child—would regularly join 
us for our weekly cell group excursions, he would normally follow in his own vehicle. I greeted him as I climbed into the front seat and asked why he was not driving himself that day. He chuckled, shook his head, and let out a sigh. 'My car has been stolen', he announced matter-of-factly. As Jaki explained it, he and his family had been on a trip to Kota Kinabalu visiting friends that week. They had pulled in at the local shopping centre to shop for gifts and other goods not available in the kampung, and when they returned to their parking site, the car was no longer there. Jaki had owned a 4WD SUV (special utility vehicle), an exceptionally valuable commodity that could manoeuvre its way around the harsh Ranau landscape and transport large quantities of oil palm from the plantation to the collection depot. Although these vehicles were common and many families owned at least one, they represented an enormous outlay and could cost up to five times the average annual household income. To have lost this was a major setback for Jaki and his family to say the least. I expressed my condolences, but to my astonishment Jaki was in good spirits. 'It will be ok', he smiled, 'As long as we have God, then we have all we need.'

I found the poised optimism expressed by Jaki in this moment of personal crisis striking. It was compounded by the fact that this loss was not only Jaki's but extended to his wife and child, who would now have to depend on others to visit the market or health clinic, as well as family and friends who had similarly called on Jaki to provide lifts and to transport goods in the past. But it was Jaki who would have to shoulder the responsibility. The way that men spoke about their cars in the kampung — durable, reliable, powerful—appeared representative of a man's virility. Such was the cost of losing one's car, I would have expected Jaki's temperament to betray the humiliation I thought he must have been feeling. Instead, he continued to joke with Alexander as we wound our way along the pockmarked highway, around hillsides scorched by deforestation, on our way to the cell group. I concluded that Jaki must be performing the local custom of remaining 'cool' by not presenting public displays of negative emotion (Chua 2012a:514). Yet, the more I reflected on the severity of Jaki's situation, the more I marvelled at his ability to sustain this 'cool' state. By his own admission, this was a terrible situation that would continue to impact him and his family for years to come. But neither he nor his wife, 'Lina', communicated feelings of personal desperation or anguish.

Certainly, this is not to say that those feelings were not felt. But Jaki and Lina's cheerfulness, which they themselves attributed to the spiritual fulfilment afforded by their faith, was remarkably persuasive in its consistency. While their response could be viewed in line with the social conditioning that suppresses publically expressed emotions among various Malaysian communities (Kuang, Wong and David 2014), it was their explicit articulation of faith that 
caught my attention. Shifting focus away from the 'sincerity' of this performance, the more interesting question became: how could (or why would) Jaki and Lina produce such enduring commitment in the face of such misfortune? What were the resources they were drawing on to process the emergence of this crisis, and how was their adjustment attuned to their attachments to the world?

A recent volume has called into question the reductive attitudes of a constructivist approach (Meyer and Van de Port 2018). Calling for more attention to be paid to how anthropological 'informants' experience the world, that is, not as social construction but through facts, Birgit Meyer and Mattijs van de Port (2018:5) outline an agenda that seeks to 'focus on the materials, techniques, skills, capacities and alternative imaginations that go into the cultural production of the real'. By exploring how my interlocutors experienced and embodied various forms of Christian Dusun subjectivity and personhood, my analysis observes the cultural framework through which their reality was produced and lived. My method for doing so incorporates the linguistic dimensions of belief, which establishes connections between personal and collective modes of articulation and self-transformation.

Taking these modes of expression as the foundation of lived experience, in this article I reflect on situations of crisis, impasse, and tragedy as I encountered them among my Sidang Injil Borneo (sıB, Borneo Evangelical Mission) Christian Dusun interlocutors. My aim is to understand how normative emotional states are regulated and encoded by a cultural framework that binds Dusun believers to a network structured by a model of Christian faith. The political urgency of this framework is heightened by the saturation of Malay Muslim social norms in Malaysia (Lim 2013). While the introduction of Christianity offers a process of social organization and spiritual fulfilment, it also provides a way of 'preserving a freedom of movement' and acts as a 'buffer' against the heavy restrictions placed on Muslims under Malaysian law (Chua 2007). The politics of belief therefore infuse collective commitments with a sense of urgency that amplifies the consequences of ideological production. While anthropologists have focused on the sincerity of the believing subject (Keane 2002), categories of belief (Robbins 2007), the politics of belief (Marshall 2009), or the rituals of faith (Miyazaki 2000), I am interested in the emotional effects of belief as it is diffused and circulated within and between believers through regimes of religious action.

\subsection{Language, Affect, and Anthropology}

Theories of affect draw on a wide range of disciplinary approaches to make visible the complex matrix of social boundaries, built environment, linguistic 
practices, and political, cultural, and economic forces that constitute bodily modes of experience in the form of 'feelings'. ${ }^{1}$ With the term 'feelings', I am referring to the emergent, embodied stimulation of the senses, while I approach 'emotions' as the cultural narratives we apply to interpret how we feel (Mazzarella 2009). Ethnographic research has revealed a number of underlying assumptions about scientific models of emotion, including the false opposition between cognition and emotion, the emphasis on emotion as an internal event, and the ascription of emotional meaning to the individual person. ${ }^{2}$ These models have developed in relation to Eurocentric taxonomies of psychophysiological processes in the body and a culturally situated category of 'personhood' that operates from essentializing constructs such as rationalism, property ownership, legal responsibility, and Western individualism. Moving away from a materialist approach that reduces emotion to its biological function, I draw on projects that expand theories of affect to consider how 'feelings' are immersed in a cultural environment that organizes experience in relation to social codes of meaning.

While the 'affective turn' in social theory has, at least in part, made a clear effort to marginalize discursive fields of representation (Guattari 1996:159; Thrift 2008), Yael Navaro-Yashin (2009, 2012) has applied ethnographic methods to reflect on the intersections of language and materiality in the production of feeling subjects. By spatializing the domain in which subjects feel, her work offers anthropology an operative lens through which landscapes emit emotive forces that are situated within processes of semiosis and intersubjective activity. Merging 'non-representational theory' with 'actor-network theory', NavaroYashin calls for a theoretical approach that considers how emotional states are transmitted as humans articulate themselves in exchange with the objects around them, and how these exchanges are located in discursive arrangements, how people 'symbolize them, interpret them, politicize them, understand them, project their subjective conflicts onto them, remember them, try to forget them, historicize them, and so on' (Navaro-Yashin 2009:15). Affect theory is a means of incorporating the vitalizing potency of objects into the programmes of action that mediate culturally constituted subjects to generate an emotional engagement within and between people and the world around them.

My application of affect looks to the generative capacity of the 'emotive domain' to structure people's social experience. In so doing, I am particularly

1 Tomkins 1962-1992; Besnier 199o; Sedgwick 2003; Stewart 2007; Thrift 20o8; Mazzarella 20o9; Berlant 2011; Massumi 2015 .

2 Abu-Lughod and Lutz 199o; Scheper-Hughes 1993; Navaro-Yashin 2012; Rumsey 2015. 
interested in the field of critical theory that has reworked post-structuralist analyses of identity to consider how normalizing social practices configure people in relation to their 'objects of desire' (Berlant 2011). In Touching feeling, for example, Eve Sedgwick (2003) explores how supposedly negative emotions, such as shame, can become an engine for the manufacturing of positive attachments, reshaping social encounters to offer space for inspiration and change. Her intervention rests on J.L. Austin's (1955) speech-act theory, which reveals how language transforms reality rather than merely representing it, seeking to dissolve the pseudo-dichotomy between subjective experience and objective reality. Demonstrating how the line between [...] linguistic and non-linguistic phenomena is endlessly changing', Sedgwick (2003:6) furnishes the anti-essentialist project with new ways to think about how emotions are 'felt' as actions in the world. Because of the normative performativity of affective attachment, feelings encode a political engagement that is always shifting the foundations of experience, destabilizing dualistic readings of, for example, nature/culture, public/private, subject/object, or individual/collective. This line of inquiry rests on the dynamic capacity of discourse to produce change in the world.

\subsection{Agency and Selfhood in the Faith Network}

As the title of this article suggests, I take up two primary questions that emerged during my fieldwork. The first is related to the meaning of faith as an affective performance of collective determination that mobilizes people to work together to realize a shared object of desire. I am interested in understanding how people construct the world through their Christian beliefs and how these beliefs materialize as feelings in response to situations of crisis, impasse, and tragedy. The combined efforts of my interlocutors, I suggest, had created an active commitment that pulsated through a network of faith, which sustained the intensive and defining mode of their relational experience. My analysis here focuses on the recursive effects of faith, that is, the generative circulation of beliefs, which involve people in a web of social relations that engender affective states that have the potential to contribute to their emotional wellbeing. The second question pertains to how these affective states might be recognized by employing the ethnographic method. Drawing on debates that interrogate the social dimensions of motivation, performance, and desire (Latour 2005; Mahmood 2005; Frank 2006), I explore how ethnography supports a methodological approach that detects how belief systems structure the emotional content of everyday life. If my argument rests on the activity of faith to generate affective states that are felt in the body, in what ways does applying ethnographic techniques of observation clarify what faith is and how it works? 
Anthropology's interest in 'agency' emerged from the questions brought about by the development of feminist theory during the 196os and 7os, which led to an increased interest in structural violence and the performance of power (Ahearn 2001:110). Ethnographic research has since shown that the concept of agency varies according to social context and that shifting regimes of action destabilize social entities such as the 'liberal subject', the 'person', and the 'self' (Mahmood 2005). Laura Ahearn's (2001:112) definition of agency as 'the socioculturally mediated capacity to act' unfastens the source of power from an essentialized individualism that makes assumptions about intention, motivation, personhood, and causality, offering instead a method that integrates social structure and performance into diverging modes of experience. Analysing the affective productivity of what I am calling 'the faith network' relies on my observation of mediating social forces between siв Dusun and objects of faith, including Tuhan (God), Jesus, Roh Kudus (the Holy Spirit), and Satan (cf. Eves 2011). Considering the complications associated with 'subjectivity' that emerge from both non-representational theory and actor-network theory, as well as the 'nondualistic' programme advocated by Eve Sedgwick (2003), it is important to qualify how I am framing the production of personhood in Ranau and how SIB Dusun notions of self interact with religious schemes.

It might be helpful at this point to address Joel Robbins's (2004, 2007, 2010) claim that Christian conversion has introduced new frameworks for thinking about the production of personhood in ethnographic contexts. Over the last decade, the cultural rupture of Christianity and its tendency to reframe social constructs has been a hot topic for debate among anthropologists. ${ }^{3}$ This robust discussion has revealed that Christian conversion can generate multiple experiences of personhood that are not centred on the Eurocentric model of Western individualism, creating new openings "between the "person" as a relational, socio-culturally constituted (non-Western) entity and the "self" as a reflexive, individualized product of a peculiarly Western history and Christian theology' (Chua 2015:341). In northern Borneo, pre-Christian Dusun sociality was governed by the egalitarian principles of adat (customary law) and organized around the nuclear family, which functioned as the basic social, economic, and political unit in the community (Rhys Williams 1965:48; Pugh-Kitingan 2017:236). Individuals were thus woven into the social fabric of the household and the community more broadly, creating bilateral kinship obligations and behavioural expectations that formed a relational, rather than essential, exper-

3 Robbins 2007, 2010; Mosko 2010; Vilaça 2011; Daswani 2011; Werbner 2011; Chua 2012a, 2012b, 2015 . 
ience of personhood (cf. Helliwell 1992). Colonial invasion, missionary expansion, and the advent of Malaysia has since transformed the semiotic framework in which Christian Dusun locate themselves in the contemporary world by introducing religious and political territories that enable people to align their identities with their kampung (village), religion, ethnic group, state, and nation, depending on circumstance (Barlocco 2014; Black 1976).

Despite these changes, the domestic environment and social organization of kampung I encountered during my fieldwork continued to resonate with etnnographic descriptions written prior to the wave of Christian conversion that swept through Sabah in the late 196os and 7os (Rhys Williams 1965; Rutter 1929). The biggest difference is the diminished influence and authority of adat (customary law), which has been reduced to the resolution of intra-village disputes and state-based land rights claims. Trevor White, one of the earliest Christian missionaries, who first arrived in Ranau in 1940, argues that it was the desire to break free from the rulings of adat, as well as the importance placed on the nuclear family and monogamy, that contributed to a straightforward transition for Dusun groups to Christian life (quoted in Elliot 1997:13). Although similar stories were espoused by my interlocutors, I do not wish to make such claims myself and, in any case, it is evident that the conversion process incorporated elements of both cultural continuity and change (Chua 2012a).

Thinking about the 'self' in this context, I agree with Liana Chua (2015:341) that 'personhood can be conceived less as an entity than as a complex and sometimes contradictory process that unfolds on multiple scales and temporalities'. Positing a theory of 'horizontal and vertical relations', she argues that both pre-Christian and Christian Bidayuh models of personhood in Sarawak, Malaysian Borneo, incorporate the intersection of 'individual' and 'dividual' impulses (see Strathern 1988; Mosko 2010), which arise from the diverse relations throughout everyday life. 'Horizontal relations' refer to those collective commitments that involve community members 'in a web of basic responsibilities and obligations', which transcend status and engender an even moral playing field (Chua 2015:346). This set of relations hinges on the moral gaze of others, compelling virtuous behaviour through public opinion and feelings such as shame. Experiencing personhood through these 'horizontal' attachments is derived from the local cultural recognition that the ideal community is cohesive, peaceful, and predominantly egalitarian. 'Vertical relations', meanwhile, indicate those spiritual commitments brought about by the acceptance and subsequent attendance to a Christian God. The 'vertical' structure of this set of relations signifies the personal and intimate relationships with God, free from the surveillance and demands of other members of the community (Chua 2015:348). This second category of relations has promoted the Christian exper- 
ience of 'reflexive, individual selves' among Chua's Bidayuh interlocutors, who are accountable for their own moral awareness, which is mediated exclusively by objects of faith (God, Jesus, Satan).

Much like Christian Bidayuh in Sarawak, my sıв Dusun interlocutors experienced themselves through these horizontal and vertical structures of attachment, articulating a shared sense of belonging that compelled people to act according to a normative model of collective personhood. Local interpretations of Christian doctrine were developed through religious exchanges both inside and outside the church, which governed the limits of emotional possibility by inculcating and reproducing social norms within a network of believers. Operating in this social system, feelings in response to challenging situations were guided by moral codes of recognition, in which the emphasis on individual desire was relegated to commitments formed through community and faith. Bringing together approaches that examine language as performative and constitutive of aspects of subjectivity with theories of affect that view feelings as both discursively generated and embodied in places, my analysis extends studies of Christian configurations of personhood to explore how language shapes feelings in terms of belief.

In his influential article 'Continuity thinking and the problem of Christian culture', Joel Robbins (2007:14) renews Talal Asad's (1993) theoretical interest in belief and, following Wilfred Cantwell Smith (1979), argues that statements of belief can be divided into two broad categories: 'believe in' and 'believe that'. To 'believe in' something conveys a commitment to act forged through trust. This form of believing is not a debatable proposition, because it expresses a personal conviction that is dependent on the conditions of the believing subject. Believing in a political ideal, for example, means acting in a certain way, not just subscribing to the idea that such an ideal exists. To 'believe that', on the other hand, denotes a level of uncertainty that ultimately leaves the proposition open for dispute. This class of belief sheds the necessary commitment implied by the former because it carries a suggestion of possible alternatives. This is detectable when, for example, a politician answers a journalist's question by beginning their statement with 'I believe that ...' as in this way they are freeing themselves from potential scrutiny by leaving room for doubt.

There are two central ideas that I wish to cultivate in light of this discussion. First, while Robbins uses this distinction to fertilize his argument about breaking away from continuity thinking in anthropological analyses of Christianity, I 
want to pursue his claim, building on Asad and Smith, that 'believing in' is not a 'state of mind' but, rather, necessitates trust, commitment, and action. Second, if Robbins's point more broadly is that belief as proposition preserves misreadings of Christian converts in anthropology by glossing over the deep change that takes place during the process of conversion, I agree with Liana Chua (2012a:513) that 'the methodological strength of his agenda [is] its attempt to align anthropological analysis with native exegesis'. It is only by taking interlocutors' statements of belief seriously — as transformative action grounded in the world-that anthropologists can observe how Christian faith structures social relationships.

One example of how language use produced such effects among sıв Dusun in Ranau was through the interpretation and application of the Malay noun kepercayaan. Sitting in on church events, I became confused about the way in which variations of the term kepercayaan were being used. Most consistently, I found, it was deployed to mean 'belief', as in 'belief in God' (kepercayaan kepada Tuhan). Other times it could mean 'trust', as in 'friendship is built on trust' (persahabatan dibuat melalui kepercayaan). Finally, in some instances, the more appropriate translation was perhaps 'faith', as in 'we must remember our faith' (kita mesti ingat kepercayaan kita). The English-language nouns 'belief', 'trust', and 'faith' share associations in meaning, and it is certainly conceivable that they could be rendered to a single word without prompting much ideological consequence. However, when I asked the pastor to explain the meaning of kepercayaan as he understood and taught it, he presented concepts of 'knowledge' (pengetahuan) and 'power' (kuasa), and scaled these back to the divergent meanings that percolate through the siв interpretation of kepercayaan:

Usually we will trust something after we find out it is right. So the truth is something that goes unquestioned. If we have no knowledge, it will not be easy for us to understand and this will have bad consequences. If we have knowledge, we have power. Trust is something we do not have to question. Feelings that are not yet strong need to be supported by evidence before they can be believed. This belief exists when we are still looking for resources to support what we want to trust. Therefore, the characteristics of faith are when we believe/trust. Therefore, if we believe in God, we must trust Him. This is faith. ${ }^{4}$

4 'Biasanya kita akan mempercayai sesuatu setelah kita menemukan sesuatu kebenaran. Jadi kebenaran itu adalah umpama sesuatu hal yang tidak dipersoalkan lagi. Sekiranya kita tidak memiliki pengetahuan, kita tidak akan mudah mengerti, sehingga itu akan menyebabkan akibat yang buruk. Apabila kita memiliki pengetahuan, kita akan memiliki kuasa. Percaya itu 
The pastor's definition of kepercayaan revolved around the ideological constructions linking knowledge and power to faith-a dominant theme of sermons given by sів pastors and church leaders during fieldwork. The discursive connection between knowledge, power, and faith underlined the informative and affective productivity of belief, while also establishing an incentive for religious action. Both knowledge and power, when applied in this context, conceptually stemmed from kepercayaan (belief/trust/faith) in Tuhan (God), as it was only through faith that Christian forms of knowledge could be developed and subsequent feelings of power realized. Likewise, bad actions were associated with a lack of knowledge, and by conceptualizing them as 'sins' (dosa), there was a moral association that was fundamental to the production of knowledge and power. This connection was indexed in the use of kepercayaan in the SIB language ideology, which represented a logic that sequentially stepped through the affirmations that Tuhan exists, that Tuhan is correct, and that serving Tuhan through action in the world gives purpose and supplies the believer with knowledge and power.

Church leaders explicitly emphasized the importance of action as an integral part of being a good Christian. The church's annual slogan in 2016 was 'Bekerja selama masih siang' (work while it is still daylight), a Biblical reference taken from John's gospel. Moral value was therefore created by 'doing' rather than 'thinking', which fostered intersubjective experience by encouraging people to be openly enthusiastic towards others and publicize their beliefs. Faith was not only an acceptance of Christian logic but also a relational process of self-articulation and transformation. The interactivity of belief in the faith network generated dynamic bonds between people, circulating feelings (as actions) that served to sustain a shared commitment to the production of Christian values.

It is important here to pause and think about the normative function of the firm, prescriptive engagement of siB ideology and how it was recognized and negotiated in the everyday lives of my interlocutors. The attraction of knowledge and power, not to mention the soteriological promise of the afterlife, affirmed a practical motivation for conforming to the expectations installed by sів ideology. Similarly, the risk of 'bad consequences' that threatened to spill out of an uninformed point of view attached a concrete urgency to moral commitment. These effects were entangled with teleological inferences, drawn

adalah sesuatu yang tidak kita persoalkan lagi. Rasa percaya yang belum terlalu kuat, perlu mencari bukti dulu baru boleh percaya. Kepercayaan ini adalah hal di mana kita masih mencari sumber untuk mendukung hal yang kita mahu percayakan. Oleh itu, ciri-ciri iman adalah ketika kita percaya. Oleh itu, kalau kita beriman akan Tuhan, kita harus percaya kepadanya. Inilah yang disebut iman.' All translations are mine unless otherwise stated. 
from Bible study, that gave life divine purpose beyond the immediacy of selfexperience. It was through these channels that faith structured the ways in which my interlocutors processed their interpretation of the present moment, while also locating a shared belonging that transcended time.

Crucially, the moral activity of faith materializes in those 'situations' that Lauren Berlant (2011:5) defines as the 'state of animated and animating suspension that $[\ldots]$ produces a sense of the emergence of something in the present that may become an event'. Power and sin were emotive norms, grounded in the body, that formed a vehicle of mediation connecting sıв Christians to the ongoing experience of self-transformation. The inflexibility of faith therefore regulated how a given situation would be animated within the purview of social interaction, even though the roles and categories determined by ideological production may not have arisen directly from the situation itself (Keane 2011:167). As a result, my interlocutors' emotional responses to situations were always governed by injunctive norms that indexed the collective, regardless of the shape an individual response might take.

Members of the siB congregation created a mutual investment in the faith network by working together to preserve their Christian values. Their commitment to the logic of kepercayaan (belief/trust/faith) was expressed as an obligation to 'do God's work', which promoted the determination to create a socially stable and cohesive community.Jaki's assurance that everything would be okay, despite his substantial loss, was an illustration of this requirement. Emphasizing the activity of belief as a condition of feeling, Jaki was able to transfer his anxiety away from the personal to be subsumed within the larger social context. He felt his respective bonds to the community, which similarly sought to lessen the burden of personal suffering that was thrust upon him by evoking the power of the collective. 'Believing in' Tuhan, for Jaki and his fellow believers, was consequently an ongoing process of moral action. Noting the pastor's explanation of the meaning of faith, the cultural framework of siB Christianity was animated by the transmission of ideals through religious instruction in church, as well as the discussions and exchanges that took place among Christians in their everyday lives. It was through these intersubjective experiences, shaped by the faith network, I suggest, that my interlocutors were able to generate forms of knowledge that could, in turn, structure their affective states. The relationship between faith and feeling therefore hinges on the social efficacy of language to transform people's experience by influencing their 'stance' (Keane 2011) within a particular situation. By taking a stance, my interlocutors sought control over how they would feel in the face of tragedy, impasse, or crisis. 


\section{How to Do Things with Belief}

The Christian beliefs of my interlocutors acted as a normative model that guided their affective states through the lived experienced of everyday life. The language ideology of sıв Christianity mediated and diffused belief by morally encoding action, as well as socially regulating how feelings became intelligible to relationally defined selves. Faith crafted a dialogic process of social realization, entwining Christian subjects and religious objects together through practices of knowledge and power and galvanizing the community by producing shared modes of religious experience. Christian belief materialized in the body as the presence of Roh Kudus (the Holy Spirit). The faith network therefore organized feelings of attachment through the circulation of an intersubjective commitment to pursue ideal emotional states, which was achieved by calling on the power of the Holy Spirit. In this section, I explore how language constructed a cultural logic that bound sів Christians together and affected their collective experience.

Language is performative and words structure social experience in a real (not merely symbolic) way (Austin 1955; Sedgwick 2003). The religious rite of baptism, for example, demonstrates the overlapping of interior beliefs and language in the production of Christian subjectivity. Once a participant has willingly performed the ritual, embracing Christ in a public forum, they have created a series of relational effects that will serve to influence how they experience themselves as a Christian, as well as how they experience others and how others experience them, even if they do not fully comprehend the magnitude of this act in its entirety when it is performed (Cavell 1995). It cannot merely be a symbolic purification of the spirit, because participants have entered into a new relationship with God and, therefore, also with sin. This admission will have obvious consequences for the way they grow into their community, which will determine their emotional attachments to the world. Such attachments redraw distinctions between inner and outer, public and private, physical and spiritual, because they all intersect in the transformative activity of self-making, which, in this case, is the act of baptism.

While the social efficacy of public ritual is evident, when considering the recursive effects of language, it is important to ask: what is the perlocutionary effect of a private statement of belief? In other words, what is the relational force of saying a prayer when no one else is there to witness it? Many of my interlocutors told me that they prayed privately to themselves several times a day. Of course, these were not 'private' acts directed internally but transcendental interactions with a powerful divinity. I want to go further, however, and claim that praying alone still involves the speaker as part of a collective religious economy that incorporates others within the faith network. 
Referring back to local exegesis, the 'self' (dirisendiri, lit. 'own self'), as it was explained to me by my interlocutors, is comprised of a body (tubuh) and a soul (jiwa). The tubuh is essentially the fleshly container for the jiwa, which houses individual consciousness (similar to Eurocentric conceptions of the mind). The pastor expanded on how these were created by Tuhan:

To create man, Tuhan came down and made man from the earth. See, we are made from the earth. Our tubuh is of the earth. If Tuhan made man from the earth, we must think what the man is going to be like. He put some feeling [perasaan] into his creation until he was satisfied: this is jiwa. So jiwa had already entered the equation-now we have tubuh, now we have jiwa. But these parts don't work yet. Humans are not alive yet. Tuhan must blow Roh Kudus into the body through the nose. He will breathe Roh Kudus into the body so he becomes alive (jadi hidup). These three things are crucial to be a person. If one of them is missing, then it is not a human anymore. If someone loses their jiwa, they have a sick jiwa. They become crazy (orang gila). They will be running around like an animal, eating dirty things. Tubuh is very important because it provides the movement. The Bible says tubuh has a problem but Roh Kudus doesn't. Tubuh and jiwa are joined. Tubuh and jiwa fight Roh Kudus because it has no problems. Roh Kudus is from Tuhan. Tubuh and jiwa are always joined together to fight Roh Kudus. For example, if there is 100orm here and nobody is around, my jiwa will always say, 'there is no one around, it is easy to take that'.

As the pastor explained, tubuh and jiwa share relations with each otherpeople spoke of them 'fighting' (lawan), for example - but also with Roh Kudus, the active emergence of Tuhan that endures as an infinite and unmeasurable divinity. When a speaker prays, he or she is partaking in a process of collective mediation that actuates the relationship between the tubuh, jiwa, and Roh Kudus. Yet, because Roh Kudus is part of the Kekudusan Tritunggal (Holy Trinity), the three consubstantial hypostases in which Tuhan is vested, the speaker is not only consolidating the divine power that is present within their own sense of self, but by calling on Roh Kudus, he or she is igniting that power in others and invigorating the affective potency of the faith network in the process.

Roh Kudus was crucial to the cultural framework that generated an emotional engagement with the world. My interlocutors spoke about a personal spirit (roh saya, lit. 'my spirit') while also referring to a universal, 'Holy Spirit' (Roh Kudus), suggesting that this was a pervasive entity that transcended the 
internal feelings of people by existing as a primary force in the world. Crucially, Malay grammar excludes the definite article 'the', which has an effect on how types of things, such as the proper noun Roh Kudus, are recognized through processes of 'typification' (Schutz 1967; Husserl 1973 [1938]:36). For example, while roh saya is attached to a person's sense of self via the possessive pronoun 'my', the semantic property of Roh Kudus is fluidly interpretable because it is unbounded by time and space. The social construction of Roh Kudus therefore contributes to its standardization as a linguistic type that assumes and inculcates its transcendental quality. When an interlocutor invoked Roh Kudus as a lexical item, such as, 'saya boleh merasakan Roh Kudus' (I can feel the Holy Spirit), they were articulating an understanding that connected Roh Kudus to Christian believers and the world around them. Unlike roh saya, which belonged somewhere at some point in time as part of a person's experiential trajectory, Roh Kudus referenced a nonlinear, deterritorialized cohesive expanse that was exchangeable with roh saya while simultaneously connected with the multiple functionalities associated with Kekudusan Tritunggal (Holy Trinity).

Talking to church leaders about this partibility, they likened Roh Kudus to wisdom (kebijaksanaan) or internal strength (kekuatan dalaman), which could be cultivated and accessed by Christian selves or, likewise, discarded and allowed to fade. As the pastor indicated: "The function of Roh Kudus is to remind you to be wise, how to act in the situation that you face, and to give you peace.' Often, when I asked other church members how they 'felt' (merasakan) Roh Kudus in their everyday lives, the common answer was that it has two 'duties' (tanggungjawab): 'to urge' (menghipurkan) and 'to help' (menolong). The 'urging' was related to the providing of peace, while 'helping' referred to the providing of wisdom. My friend Alexander explained to me that

if I go to a funeral then of course I feel sad. But I can still control myself. We can still smile. We can still give thanks to Tuhan because this happened to me. Others might be surprised and ask how I can still smile in this situation. Roh Kudus will look at the situation. It is not like magic when you perform a spell and the bad things go away. The time when Roh Kudus can do something in your life is when you read the Bible. When the word of Tuhan is in you. If there is nothing in you, how can Roh Kudus remind you to do something? Roh Kudus helps by reminding you that Tuhan is there with you. My life is up and down. When I pray a lot and read the Bible, my thinking becomes very high. My standard, my quality in action and in thought, it becomes very high. When I pray less, when I read the Bible less, I really feel it in roh saya. It goes down. 
Alexander's account highlights a number of important features that contribute to the affective potency and collective efficacy bound to his experience of Roh Kudus. First, he confirmed that, much like anyone who suffers loss, he will feel sad (sedih) at a funeral. While it is socially acceptable to feel sad, he posited an implicit moral obligation to project a particular emotional expression (smile). Alexander's emphasis on communicating this expression suggests that the scale of emotional meaning remains interlinked with the other funeral attendees. Crucially, his feelings were conceived of as actions, which were to remain aligned with his commitments to Tuhan and the community. Second, he claimed that by praying a lot and reading the Bible, he was able to access the influence of Roh Kudus. Dismissing the notion of magic, which was often viewed as either an illusion or an act of Satan, Alexander asserted that Roh Kudus 'can do something in your life [...] when you read the Bible'. Referring to the emotive force of Roh Kudus to act on the conditions that he might face, the 'doing' was grounded in the capacity for Roh Kudus to 'look at the situation' and thus provide valuable insights that an individual acting alone might fail to grasp. Third, this intervention could only take place if 'the word of Tuhan is in you'. sıв Dusun subjectivity, according to Alexander, was therefore a constant process of internalizing Christian discourse and reproducing guided feelings (such as smiling) through religious action (praying). These feelings were directed, more often than not, by the moral requirement to be grateful to Tuhan. It was through this act of gratitude that Alexander claimed to be able to 'control' (kawalan) himself.

The notion of control, which I will take up further in the next section, raises an interesting set of questions that position the role of desire-what one wants or how one feels compelled to act-in an affective relationship with the mediating forces of religious objects. The instinctual urge to cry at a funeral, for example, is situated in dialogue with the 'voice' of Roh Kudus and the 'word' of Tuhan. This exchange of acts operated to structure the ways in which my interlocutors felt. One story that circulated in the church, which I heard in various iterations, animated the experiential control that emerges from the religious economy of the faith network:

A Christian associate in Brunei had been arrested for publically advocating Christianity. Detained in a police cell, she was overcome with fear. Suddenly, Roh Kudus reminded her of what she had read in the Bible and to be wise. After that, she relaxed and felt peaceful. The police could no longer question her because her answers were too clever. Later she was released without charge. 
This anecdote, which recalls biblical stories of Jesus outwitting his accusers, demonstrates how language plays a clear role in the transmission of sів social norms and values by invoking a culturally specific understanding of what Roh Kudus is and how it works in the world. My interlocutors' explanation of their ongoing relationship with Roh Kudus, which was augmented by the bodily experience of their own spirit, preserved a moral commitment to act according to injunctive norms made explicit through theological teachings. These commitments were formed as part of a relational framework drawn from a non-propositional 'belief in' Tuhan. Intersubjective exchanges between people and Tuhan, involving the spiritual form of Roh Kudus, determined a dialogic process that structured the experience of my interlocutors, working to guide their 'feelings' (as actions) in response to situations of personal crisis.

As mentioned above, a personal spirit (roh saya) was carried by individual 'selves' but also subsumed into Roh Kudus, the active presence of Tuhan in the world. The composite, partible construction of roh saya and Roh Kudus destabilizes how we might think of зів Dusun notions of selfhood as an individually coherent, essentially bounded subject. In the same manner as Liana Chua's (2012) Bidayuh interlocutors in Sarawak, the social construction of siB Dusun persons in Ranau is partly a process of 'horizontal' relations with other members of the community, as well as 'vertical' relations with Tuhan. The intersection of these relationships worked to constitute personhood as a product of both social and religious responsibilities. By collectively pursuing divine knowledge, my interlocutors organized their experience with respect to objects of faith, such as Tuhan, Jesus, Roh Kudus, and Satan. Locating the faith network as an encounter with reality mediated by spiritual actors and actants, 'belief in' these objects offered a vehicle for bodily regulation, ultimately empowering people to manipulate their emotional experience. Having surveyed the positive affective potency of religious objects to generate forms of knowledge and power in the faith network, this section investigates the importance of 'sin' $(d o s a)$ as an equally powerful relational force in the religious economy of siB Christianity.

According to Christian doctrine, humans are born into sin. This was explained to me by 'Michael', a dashing young church member who had recently returned to the kampung from the city to reform from a life hardened by crime. One evening after a midweek church service he told me: 
First [as] people [we] have to admit that we are sinful. With our thoughts, with our actions, with our conversation, and our mouths - everything we do is sin. The church represents the place we are going to meet for forgiveness. So, the church becomes a hospital for sick people when we acknowledge that we are sinful.

Sin is conceptualized as stemming from a sick soul (sakit jiwa), which occurs when there is a problem in the relationship between the body (tubuh) and spirit $(r o h)$. Michael explained this with the following example:

The first time I steal, my heart is beating very fast. This means that roh saya is still active. But if the second time I steal my heart is more relaxed and after many times it becomes normal, then roh saya is still there but is no longer active. I can no longer hear the voice of Roh Kudus.

After repeatedly ignoring the emotional guidance of his spirit, Michael said that it is normal that a person develops hati nuraniyang tumpul (a blunt conscience). Crucially, a person's conscience resides in the heart (hati), anchoring the moral potentiality of the self to the body. The capacity to carry out good actions requires the heart to receive Roh Kudus into the body and to 'listen' to its 'voice'. Bad actions, or sin, are a contravention of this externalcum-internal voice. Michael explained that when he went to the city, he found that he no longer felt the power of Roh Kudus, as he had done when he was in the kampung. The attrition of Roh Kudus, catalyzed by the growing costs of urban life and exposure to a new social scene not constrained by the obligations of familial sociality, is how Michael articulated his transition into a life of crime. Acclimatizing to a lifestyle regulated by the demands of capital, he found himself released from the influence of Roh Kudus, which he identified as the inevitable cause that led him to commit sin.

Having reached an impasse, Michael returned to the kampung. He told me that upon his arrival he could immediately feel the presence of Tuhan. This presence acted upon his body to heal (sembuh) him. After investigating sib use of the word 'sembuh', which is associated with the curing of physical illness, it became clear that even while people recognized a difference between physical and spiritual forms of sickness, these categories were blurred because of their equal potential to produce negative outcomes. Whether pathologically ill from disease or spiritually ill with sakit jiwa (sick soul), the afflicted was no longer in control of their body. 'Healing' was therefore a process of aligning the tubuh (body) and jiwa (soul) with the voice of Roh Kudus, calling on the partible pres- 
ence of Tuhan, within the emergent power of the faith network, to enter the sick person and help reinstate control.

The relationship between illness and a concept of the 'soul' has been depicted in many pre-Christian ethnographies in Borneo. ${ }^{5}$ In Dusun communities, penyakit (sickness) was associated with feelings of pain, stemming from a variety of causes, including 'illness and uneasiness and anguish from being maligned or slandered' (Rhys Williams 1965:35). This inclusive interpretation of illness was scaled to a causal relationship between people and their environment, in which undesirable situations (such as community-wide crisis or personal disease) were linked to a 'hot universe'. Crucially, an explanation that traced the cause of illness to events occurring in the world meant that one could prevent or treat illness by enlisting a specialist to manipulate those events through the performance of ritual action. In his account of a preChristian Dusun group in Tambunan, Thomas Rhys Williams (1965:36-45) describes how male ritual specialists would 'call directly to the creator' with the assistance of 'spirit objects' (stone or wood figures). Here, people were believed to contain seven souls, and some illnesses were thought to originate from the struggle of a soul to leave the body of a person who had committed offenses against the creator. This ethnographic representation indicates that Dusun understandings of illness have historically incorporated a variety of causes, ranging from the social (gossip, black magic) to the spiritual ('hot universe'), and that sickness could be alleviated by practices that use mediating actants to influence the spiritual forces at play in the world.

The conflation of pathological and spiritual sickness in contemporary constructions of sakit was colourfully demonstrated when I fell seriously ill with a double dose of dengue fever and food poisoning during the final phase of my fieldwork. With the early onset of dengue, which included nausea and body pains, my hosts called the pastor to pray for me. And then, while I feverishly drifted in and out of consciousness, members of the household and other close friends entered my room to hold a vigil. The hospital, several hours away by car, was considered to be a last resort. As I later found out, the healing powers of Tuhan were not necessarily thought to be superior to the medical powers of science, nor was my illness interpreted as deriving from my soul. Rather, the life-preserving influences of Tuhan and human medicine act differently upon the body and, although I was suffering from an acute pathological disease, my hosts sought to infuse me with the strength and calm of their faith. In the end, when I sought medical treatment in the city, I was advised to take the

5 Rhys Williams 1965:44; Sutlive Jr. 1976:68; Metcalfe 1976:80; Chua 2012:71. 
power of Tuhan with me to complement the power of the healthcare professionals.

While Tuhan was located as the prime actor in the healing process, the charisma of the community was required to produce an effect. When I asked Michael how important the community was in his personal healing experience, he told me: 'If you burn one matchstick the fire will go out, but if you burn a chain of matches the fire will burn brighter.' This attitude was supported by 'Kennedy', an up-and-coming youth leader with a prominent role in the church, who explained that 'maybe I am not confident even though I pray for someone to be healed. But if my companion is confident then it will help make me confident too. If my faith is not strong, the others will make my spirit stronger'. Reliance on others within the network to consolidate faith was therefore acknowledged as playing a significant role in sustaining the efficacy of Tuhan, who could, in turn, enact the process of healing.

Negative emotions, such as fear (ketakutan in Malay, kororosian in Dusun), anxiety (kebimbangan in Malay, kakangaawan in Dusun), sadness (kesedihan in Malay, osundu/osodi in Dusun), and anger (kemarahan in Malay, otogod in Dusun), were all associated with a loss of control (kehilangan kawalan), which was, in turn, conceived as originating from spiritual illness or a 'sick soul' (sakitjiwa). While church leaders often preached that Roh Kudus is an 'internal strength' (kekuatan dalaman) that must be exercised in order to remain potent, when I asked sıв Christians how they felt Roh Kudus in everyday life, the most common response was 'peace' (damai) or 'calm' (tenang). Much like a person's conscience, the negative emotions that lead to a loss of control were perceived to be located in the heart (hati).

This relationship between the body and emotions, and how it was felt by my interlocutors, became salient when a prolonged drought threatened the season's rice harvest. Upon returning from the garden one sunny afternoon, the matriarch of my adopted household declared: 'We are facing problems this year, I can feel it in my heart.' However, this grave forecast was not expressed with the solemn tone and heavy mannerisms I might have (again, rather naively) expected. Instead, her temperament remained light and full of good humour. Sensing that her apparent good mood was inconsistent with the impending severity of an oncoming drought, I asked her how she could remain cheerful in this situation. She grinned, saying: 'Tuhan will remind me what to do. He will help me solve this problem.' The stress caused by drought was softened by the matriarch's faith, which provided her with the 'knowledge' (pengetahuan) and 'power' (kuasa) to control her heart. Come harvest time, there was not enough rice to share with family members in the city, but there was still enough to sustain the household. The issue was consequently exposed 
as an emotional problem that had threatened to unsettle her body with anxiety, confirming her reliance on faith to mediate the problem as the correct response.

\section{5}

\section{Teen Pregnancy: The Moral Dimensions of Faith}

When I returned to my fieldsite at the beginning of 2018 , I was greeted with the regular rounds of local gossip. Besides the commonplace misadventures and disagreements, there was news that was genuinely concerning. Since I had been gone from the kampung, one of the young women in the church youth group had become pregnant at sixteen years of age. Bearing a child out of wedlock, particularly before graduating high school, is considered a grave sin, and I worried that the community would conjure her pregnancy as an act of sakit jiwa (a sick soul) and how this might affect an already vulnerable young woman. She had since gone into hiding, with her whereabouts known perhaps only to her mother, and so the controversy had become a discursive drama that called attention to moral questions in the community about individual guilt and the function of faith as a positive, restorative apparatus of emotional empowerment.

Contemporary Dusun societies, like other adat-based societies in Borneo, emphasize 'coolness' (ketenangan, lit. 'calmness') as the ideal state through which the kampung maintains social stability (Chua 2012:514; Rhys Williams 1965:29). Temperature here not only acts a metaphor for remaining levelheaded but is also physically grounded in bodily states. When a person has a sakit jiwa and loses control, the body of the sick is regarded as panas (hot). Likewise, when a person is calm, their body is sejuk (cool). Similarly, exchanging damaging rumours about others can cause people to feel upset, which is referred to as telinga panas (hot ears, or 'spreading rumours') and hati panas (hot heart, or 'upsetting someone') respectively. Not wanting to heat anyone's hearts or ears, my knowledge of the situation with the pregnant youth was limited to the trickle of information that would be offered in private moments with close associates. Conversations could therefore be directed to the attitudes of particular community members and their response to what they considered to be a moral crisis.

Speaking with a number of my closest interlocutors, it became apparent that people within the faith network acted to mutually constitute a common good, to the effect that the church assumed a level of responsibility for the moral virtue of all members in its congregation. This responsibility was framed as both preventive education and palliative care. As one person remarked: 
We are Christian, so we know that Jesus is the tree and we are the branch. We have to help each other. If someone has made a mistake, we have to remind them and help them. The pregnant girl was active in the ministry before she was pregnant. We have to teach her before she has a problem. Once a problem occurs, we have a responsibility to support her.

The imagery of the tree furnishes Christian modes of belonging with cooperative reciprocity, clarifying that individual Christian 'branches' are joined together by their affinity in Christ. Just as branches make up component parts of the life system of the tree while at the same time remaining individual units, each Christian is expected to contribute to the wellbeing of the community, while also controlling the temptations of the flesh that drive individual desire. Moral responsibility is therefore reticulated through the community, so that people within the faith network rely on others to create a common good. This model of social production meant that sıв Dusun were obligated to act in the interests of Tuhan, who was revealed through the presence of Roh Kudus.

In the case of a moral crisis, such as a teen pregnancy, the sins of humans were supposedly excluded from moral judgement by other humans, which was solely reserved for Tuhan. As another person explained to me, 'We have no right to judge these youths'. The crisis was therefore not purely attributed to those individuals who committed a sin but also to those whose responsibility it was to educate and safeguard them. As such, it had to be managed by the church as a whole. However, there were requirements that these young sinners had to fulfil before they could be welcomed back into the church. Both the pregnant youth and her male accomplice were expected to address the community at church service, give testimony, and repent (they had not done this at the time of my fieldwork). Meeting with church leaders, they were to receive counselling before being given a three-month probation period. Through these acts of reconciliation with the church, the young perpetrators would be able to resolve the crisis and re-enter the community as 'good' Christians. The restriction on (public displays of) judgement shifted community responses away from sustained condemnation and focused attention on regenerative acts of reconciliation.

These conciliatory acts were to atone for what was framed as a dosa umum (public $\sin$ ), which was explained to me as sin that is within the realm of public knowledge. Offences that would normally fit into this category included stealing, cheating, and mild acts of violence. One church leader provided an example: 'When I hit you, you can call my family or your friends. Everyone will become involved.' Because the news had spread very quickly among the community, generating universal kasihan (pity), in this case the two youths had 
to repent during a church service, giving an apology that would make room for Tuhan's forgiveness. However, there was another moral layer to this scenario. The family of the young woman expected payment from the family of the young man; specifically, thirty thousand ringgit and a cow. This payment was in retribution for what was framed as dosa eksklusif (personal sin), a category of sin that was serious and personal, having an effect on generations beyond the immediate victim. The offences that could be classified as dosa eksklusif included adultery, rape, and murder. Under normal circumstances, the church leader explained, 'if someone commits dosa eksklusif they cannot confess to the church because maybe it is not common knowledge. It is a private matter. The sinner has to confess, give testimony and repent to those who have been effected by the sinful act.' Because the community shared in the pity caused by the pregnancy, it became both a dosa umum and a dosa eksklusif.

The teen pregnancy articulated a common thread I often encountered in conversation with Christians in Ranau. Although people have individual souls and bodies, all Christians share in the power of Roh Kudus, which is felt in the body, thus blurring the qualities that constitute people as separate social units. If someone achieves success - for example, in their business or school assessment - it is interpreted as a manifestation of Roh Kudus, which is a collective experience to be celebrated by everyone within the faith network rather than an individual achievement that could give rise to an inflated sense of harga diri (self-worth). Crises are construed in a similar fashion, which compels Christians to act on, and take responsibility for, a bad situation. This give-andtake between people establishes a social cohesiveness that allows people to mutually depend on each other and distribute the value of their actions across the network.

The pregnant teen did not reappear while I was completing fieldwork in Ranau, although I later heard through friends that she had successfully given birth and married the father, who had paid the fines, and they were now living with her parents in the kampung. Even while the church acted to support the prospects of these young sinners, the production of ethical norms always demarcates the boundaries of social inclusion. Feelings of rejection and self-doubt are folded into the experience of community, fracturing a unified interpretation of a moral subject (Keane 2011:167-8). Therefore, while the affective attachments that emerged from sıв Dusun modes of subjectivity offered a vehicle for emo- 
tional empowerment and collaboration, acting against this commitment could threaten to destabilize psychological wellbeing and become equally destructive. The young woman's retreat into hiding highlights the anxieties that accompany acting outside the borderlines of collective belief. The negative moral association with 'losing control', falling victim to sakit jiwa (sick soul), could also be viewed as the inability, or unwillingness, to conform to the social structure prescribed by sів Dusun ideology. However, in conjuring a response to situations of crisis, impasse, or tragedy, my interlocutors were consolidating processes of 'typification' in which knowledge and power were recognized as products of faith, embodied in and communicated by their experience of the voice of Roh Kudus. The articulation of belief therefore determined the vectors of emotional possibility.

If research on emotion in anthropology has been supplanted by an ethnographic turn toward a greater focus on the relations between 'subjectivity', 'embodiment', 'personhood', and 'experience', as Andrew Beatty (2013) persuasively argues, the puzzle shifts to a concern about how these interrelated modes of analysis can help ethnographers to better understand the cultural processes that constitute the affective states of (un)consciousness that drive action in the world. In this article, I have presented an account that explores how affective states are constituted by the interactive engagement between subjects and their cultural environment as an assessment of belonging that is situated within discursive arrangements and social codes of meaning. In so doing, I have been cautious not to 'emotionalize' the feelings of my interlocutors; that is, to misrecognize and map specific conceptual readings of emotion, such as happiness or sadness, onto their lived experience. Emotions, in this sense, are not so much 'complex narrative structures that give shape and meaning to somatic and affective experiences' (Shweder 1994:37) but, rather, a process through which affective experience and meaning combine to produce embodied modes of negotiating the world. As a result, I have been wary of the role of representation and interpretation that lies at the heart of the ethnographic method. Instead of unearthing narratives of Christianity and emotion simply to reveal their emergent meanings, I have sought to trace the effects of social attachments fuelled by a mutual investment in spiritual fulfilment and to understand sıв Dusun subjectivity on its own terms.

Merging linguistic models of performance with theories of affect, I have shown that the production of siв Dusun personhood in Ranau contributes to the formation of shared religious experience, felt in people's bodies as 'power' motivated by the voice of Roh Kudus, connecting sів Dusun to Tuhan through a network of belief. The faith generated from this network, I suggest, was part of a multilevel process of self-articulation that had the potential to regulate 
feelings in response to undesirable situations. Crucially, 'believing in' has the effect of structuring peoples' social experience around objects of desire, even if the pursuit of these objects can lead to disaffection or exclusion (Berlant 2011). Belief-as-non-proposition is accordingly always political, as collective desires develop in relation to shared beliefs, which stimulate social, economic, and political forces that act on the conditions through which people negotiate their presence in the world. In this sense, I agree with Michelle Rosaldo (1984:142) that 'selves and feelings, shaped by culture, may be understood in turn as the creation of particular sorts of polities'. In Malaysia, where social norms at large are governed by the ideology of an increasingly conservative Islam, the political urgency of feeling subjects who operate beyond these borderlines is perhaps more critical than ever.

\section{References}

Abu-Lughod, Lila and Catherine Lutz (1990). 'Introduction: Emotion, discourse, and the politics of everyday life', in: Lila Abu-Lughod and Catherine Lutz, Language and the politics of emotion, pp. 1-23. Cambridge: Cambridge University Press.

Ahearn, Laura (2001). 'Language and agency', Annual Review of Anthropology 30:10937 .

Asad, Talal (1993). Geneologies of religion: Discipline and reasons of power in Christianity and Islam. Baltimore: Johns Hopkins University Press.

Austin, J.L. (1955). How to do things with words: The William James Lectures delivered at Harvard University in 1955. London: Oxford University Press.

Barlocco, Fausto (2014). Identity and the state in Malaysia. New York: Routledge.

Beatty, Andrew (2013). 'Current emotion research in anthropology: Reporting the field', Emotion Review 5-4:414-22.

Berlant, Lauren (2011). Cruel optimism. Durham: Duke University Press.

Besnier, Niko (1990). 'Language and affect', Annual Review of Anthropology 19:419-51.

Black, I.D. (1976). 'Interethnic relations and culture change under colonial rule: A study of Sabah', in: George Appell (ed.), Studies in Borneo societies: Social process and anthropological explanation, pp. 27-42. DeKalb: Center for Southeast Asian Studies, Northern Illinois University.

Cavell, Stanley (1995). Philosophical passages: Wittgenstein, Emerson, Austin, Derrida. Cambridge: Blackwell Publishers.

Chua, Liana (2007). 'Fixity and flux: Bidayuh (dis)engagements with the Malaysian ethnic system', Ethnos 72-2:262-88.

Chua, Liana (2012a). 'Conversion, continuity, and moral dilemmas among Christian Bidayuhs in Malaysian Borneo', American Ethnologist 39-3:511-26. 
Chua, Liana (2012b). The Christianity of culture: Conversion, ethnic citizenship, and the matter of religion in Malaysian Borneo. New York: Palgrave Macmillan.

Chua, Liana (2015). 'Horizontal and vertical relations: Interrogating "in/dividualism" among Christian Bidayuhs', HAU:Journal of Ethnographic Theory 5-1:339-59.

Daswani, Girish (2011). '(In-)dividual Pentecostals in Ghana', Journal of Religion in Africa 41:256-79.

Elliot, Peter (1997). Asang: The story of Trevor White and the Dusuns of Sabah. Cleveland, Queensland: Delia Wilson.

Eves, Richard (2011). 'Pentecostal dreaming and technologies of governmentality in a Melanesian society', American Ethnologist 38-4:758-73.

Frank, Katherine (2006). 'Agency', Anthropological Theory 6-3:281-302.

Guattari, Felix (1996). 'Ritornellos and existential affects', in: Gary Genosko (ed.), The Guattari reader, pp. 158-71. Oxford: Blackwell.

Helliwell, Christine (1992). 'Good walls make bad neighbours: The Dayak longhouse as a community of voices', Oceania 62-3:179-93.

Husserl, Edmund (1973). Experience and judgment. Evanston: Northwestern University Press. [First published 1938.]

Keane, Webb (2002). 'Sincerity, "modernity", and the Protestants', Cultural Anthropology 17-1:65-92.

Keane, Webb (2011). 'Indexing voice: A morality tale', Journal of Linguistic Anthropology 21-2:166-78.

Kuang Ching Hei, Wong Ngan Ling and Maya Khemlani David (2015). 'The perceived value of silence and spoken words in Malaysian interactions', The Journal of the South East Asia Research Centre for Communications and Humanities 7-1:53-70.

Latour, Bruno (2005). Reassembling the social: An introduction to actor-network theory. Oxford: Oxford University Press.

Lim, Regina (2013). 'Islamization and ethnicity in Sabah, Malaysia', in: Hui Yew-Foong (ed.), Encountering Islam: The politics of religious identities in Southeast Asia, pp. 1589o. Singapore: Institute of Southeast Asian Studies.

Mahmood, Saba (2005). Politics of piety: The Islamic revival and the feminist subject. Princeton: Princeton University Press.

Marshall, Ruth (2009). Political spiritualities: The Pentecostal revolution in Nigeria. Chicago: University of Chicago Press.

Massumi, Brian (2015). Politics of affect. Cambridge: Polity Press.

Mazzarella, W. (2009). 'Affect: What is it good for?', in: Saurabh Dube (ed.), Enchantments of modernity: Empire, nation, globalization, pp. 291-309. New York: Routledge.

Metcalfe, Peter (1976). 'The Berawan afterlife: A critique of Hertz', in: G.N. Appell (ed.), Studies in Borneo societies: Social processes and anthropological explanation, pp. $72-$ 9o. DeKalb: Center for Southeast Asian Studies, Northern Illinois University. 
Meyer, Birgit and Mattijs van de Port (2018). 'Introduction: Heritage dynamics; Politics of authentication, aesthetics of persuasion and the cultural production of the real', in: Birgit Meyer and Mattijs van de Port (eds), Sense and essence: Heritage and the cultural production of the real, pp. 1-40. New York: Bergahn Books.

Miyazaki, Hirokazu (2000). 'Faith and its fulfilment: Agency, exchange, and the Fijian aesthetics of completion', American Ethnologist 23-1:31-51.

Mosko, Mark (2010). 'Partible penitents: Dividual personhood and Christian practice in Melanesia and the West', Journal of the Royal Anthropological Institute 16-2:215-40.

Navaro-Yashin, Yael (2009). 'Affective spaces, melancholic objects: Ruination and the production of anthropological knowledge', Journal of the Royal Anthropological Institute (N.S.) 15:1-18.

Navaro-Yashin, Yael (2012). The make-believe space: Affective geography in a postwar polity. Durham: Duke University Press.

Pugh-Kitingan, Jacqueline (2017). 'An overview of cultural research in Sabah', in: Victor T. King, Zawawi Ibrahim, and Noor Hasharina Hassan (eds), Borneo studies in history, society and culture, pp. 235-61. Singapore: Springer.

Rhys Williams, Thomas (1965). The Dusun: A North Borneo society. New York: Holt, Rinehart and Winston.

Robbins, Joel (2004). Becoming sinners: Christianity and moral torment in a Papua New Guinea society. Berkeley: University of California Press.

Robbins, Joel (2007). 'Continuity thinking and the problem of Christian culture: Belief, time, and the anthropology of Christianity', Current Anthropology 48-1:5-38.

Robbins, Joel (2010). 'Melanesia, Christianity, and cultural change: A comment on Mosko's "partible penitents"', The Journal of the Royal Anthropological Institute 162:241-3.

Rosaldo, Michelle (1984). 'Toward an anthropology of self and feeling', in: Richard Shweder and Robert A. LeVine (eds), Culture theory: Essays on mind, self, and emotion, pp. 137-57. Cambridge, Uk: Cambridge University Press.

Rumsey, Alan (2015). 'Language, affect and the inculcation of social norms in the New Guinea Highlands and beyond', The Australian Journal of Anthropology 26:349-64.

Rutter, Owen (1929). The pagans of North Borneo. London: Hutchinson.

Scheper-Hughes, Nancy (1993). Death without weeping: The violence of everyday life in Brazil. Berkeley: University of California Press.

Schutz, Alfred (1967). The phenomenology of the social world, translated by George Walsh and Frederick Lehnert. Evanston: Northerwestern University Press.

Sedgwick, Eve (2003). Touching feeling: Affect, pedagogy, performativity. London: Duke University Press.

Shweder, Richard (1994). "'You're not sick, you're just in love”: Emotion as an interpretive system', in: Paul Ekman and Richard J. Davidson (eds), The nature of emotion: Fundamental questions, pp. 32-44. New York: Oxford University Press. 
Smith, Wilfred Cantwell (1979). Faith and belief. Princeton: Princeton University Press. Stewart, Kathleen (2007). Ordinary affects. Durham: Duke University Press.

Strathern, Marilyn. 1988. The Gender of the Gift: Problems with Women and Problems with Society in Melanesia. Berkeley: University of California Press.

Sutlive Jr., Vinson (1976). 'The Iban Manang: An afterlife route to normality', in: G.N. Appell (ed.), Studies in Borneo societies: Social processes and anthropological explanation, pp. 64-71. DeKalb: Center for Southeast Asian Studies, Northern Illinois University.

Thrift, Nigel (2008). Non-representational theory: Space, politics, affect. London: Routledge.

Tomkins, Silvan (1962-1992). Affect, imagery, consciousness. New York: Springer. Four vols.

Vilaça, Aparecida (2011). 'Dividuality in Amazonia: God, the Devil and the constitution of personhood in Wari' Christianity', Journal of the Royal Anthropological Institute 17-2:243-62.

Werbner, Richard (2011). Holy hustler, schism, and prophecy: Apostolic reformation in Botswana. Berkeley: University of California Press. 